\title{
THE LANGUAGE OF CRISIS AND THE PROBLEM OF HISTORICAL MEANING NiETZSCHE, HEIDEGGER, KOLAKOWSKI
}

\author{
Gabriel Popa \\ West University of Timisoara; \\ Romania, 300223 Timisoara, 4 "Vasile Parvan" Boulevard \\ E-mail address: gabrielpopa19@gmail.com
}

\begin{abstract}
The main task of our paper is to emphasize the relationship between the dominant historical paradigm which emerges at the end of the $19^{\text {th }}$ Century and the contemporary embrace of crisis language. We will see that the dawn of the historical school and of historicism in general brings forth the dissolution of the last remains of the Absolute figures, thus leaving us in front of desolation and emptiness. Post-modern skepticism and relativism became the dominant features that shape our intellectual and moral landscape, trapping us within a seemingly inescapable situation of crisis which finds its own language and expressions. Our journey will trace back to the origins and main motivations of what has been described as a constancy of the post-modern condition as it is described by Kolakowski in one of his essays from 1989, finding along our way writers like Heidegger and Nietzsche which we think are our best witnesses of the main variations of the relation between the meaning of history and the crisis-consciousness.
\end{abstract}

Keywords: crisis, history, relativism, Kolakowski, Nietzsche, Heidegger

\section{PRELIMINARY REMARKS: CRISIS AS THE WORD OF THE DAY}

Since the beginning of the twentieth century, crisis has became one of the most familiar words in our everyday language. We use and abuse it, in order to express any type of difficulty that we encounter, witness or that we hear of. Recently, we have all heard about the crisis in Greece which means the collapse of its financial system that could end with a collapse of its institutional organization and the possibility of a complete bankruptcy of a country, at all levels. Nobody really knows what to expect from such an apocalyptical image, and our experience is radically different from the one that an inhabitant of Greece has. As a financial crisis, it may be considered the outcome of the general crisis that has drawn most of the European countries into recession in the last few years. But, in the same period, we heard of another crisis, this time a political one, which has taken place in Ukraine, when Russia has decided to occupy one of the country's regions, Crimea, an event that brought us in the proximity of an open war. There are some other kinds of crisis that usually follow some natural disasters, like earthquakes 
and tsunamis. Some of us are anticipating the crisis that may finish the human race, as a consequence of the global warming caused by the continuously increase of polluting emissions of a hyper-technologized era. Religion is in crisis, culture is in crisis, and of course, we are passing through all types of personal crises. Only science knows a furious progress which will soon become, if it hasn't become yet, the final answer for all our questions and uncertainties.

But if we take a closer look at this catastrophic imagery, it may seem out of time, even if just because, at least at a large scale, we have never been part or even witness some terrifying events like a world war. This is true at least for the vast majority of us. We may say that our crisis vocabulary is a reminiscent of an old(er) era which has gone through real war, in such a way that people were real witnesses of a complete disintegration of all their traditional establishments, political, economical, cultural, their families were broken, and a sense of general disorientation is brought forward trough the majority of cultural products of the first part of the twentieth century, one of the most vehement vehicle of this public sensation being Spengler's book written between the two world wars, Decline of the West ${ }^{9}$.

Following the way the word crisis has been used within recent decades, we may see that its reference has spread, therefore its meaning has changed. It is mostly used now in order to designate some disorder in our personal affairs, regardless if we are talking here about psychic disorders, family problems, our feelings, or our professional life. Following a Cartesian account, we are probably the best witnesses of our internal states, the corollary being that the same internal states are usually difficult, if not impossible, to be presented to somebody else. And for all of that, when something is not working, or it's going in the wrong direction, we came into an inheritance, and this is the word crisis. This tendency, even if it is not explained in the same way, is expressed in Francis Fukuyama's The End of History and the Last Man, a book that was written at the end of the anticommunist revolutions from the 1990 's, where the author posits the idea of the end of history in a reconsideration of Hegel's idea of a finality of the historical process, that is considered not as the end of historical events, but as the final stage of the social organizing evolution, allowing a mutual, universal recognition of human rights. The end of history is the victory of the self-preservation instinct over the brutality of the fight for recognition that is said to be the fundamental feature of the origin of any civilized society (Fukuyama, 1992). But, as always, there is a counterpart for this statement, and this is a sense of discontent, of uneasiness, that is one of the most familiar sensation of our present days, and that is best described in Freud's Civilization and its Discontents from 1930. Recently, there are many researches that show that the growth of civilization is often accompanied by a growth in psychic disorders, of which the most important is psychic depression, one of the most informed and convincing analyses of this contemporary phenomenon being the Anatomy of Depression written by Andrew Solomon in 2001.

9 "Crisis" became the key word for all aspects of ordinary or scientific life, in special Germany, after the first Wordl War. For an excellent analysis of the cultural life in Germany in that period, see Bambach, especially cap. I.3. 
All of the authors that were mentioned before have, indeed, different premises, methodology and goals. But the common word is that we should somehow find a solution to a critical dialectic, a third element that would reconcile some opposing traits of our contemporary society and life. This opposition may be expressed as one between some human fundamental instincts as in Fukuyama and Freud, one between the goals that are imposed on all of us within the civilized societies and their emptiness as in Solomon, or one between the factual historical process and the trans-historicity of the divine time, as in Berdiaev's Meaning of History.

Crisis has become commonplace, and it is being used, indiscriminately, in order to express almost any problem that may affect, in one way or another, one of our life domains. We may hardly find such an area that has been privileged to remain unexposed to crisis, and we have already highlighted the usual domains in which crisis has already made its apparition, starting with our own psychic and ending with the doom that may be brought upon us by, curiously enough, the only domain that seems without interruption, the scientific progress. Regarding the latter, this is a very promising domain that may be discussed, and it has been already, especially the relation that science has with ordinary life, the fact that science seems to part ways with life, in both language and aims. The bibliography here is one of the largest that we may find, while here I'm only referring the potential reader to Heidegger's debate with technology, Husserl's Crisis of the European Sciences, and the recent publications of Stephen Hawking. In the same time, one of the most influential analyses of the meaning of the concept of crisis has been brought forward by a theoretician and historian of sciences, and we are talking about Structure of Scientific Revolutions of Thomas Kuhn. This is a book about the history of sciences and of the scientific discourse, which is revealed as a history of how sciences have succeeded in overcoming their crises, in order to leave us with the impression that it is the most successful domain of intellectual life.

But a proper analysis of the relationship between science and ordinary life is something beyond our concern here, while the latter has not been yet even addressed. In order to do so, we will state our main content, that our current way of talking about crisis is somehow an un-reflected inheritance and an expression of an underlying conception about historical progress and its meaning. In both usual and scientific language, crisis is something of an interruption of some chain of events in such a way that the object that has been affected by a crisis is reconsidered, being extracted from its everydayness. We may then look at the causes that determined that crisis, mostly in order to find a way to set things back on their usual track. This is a second determination of the contemporary talk about a crisis, the latter being regarded as something that has to be overcome, while the entity affected has to be cured, since crisis is not something that would normally characterize a prolonged or a definitive state of affairs. Crisis is temporary, and this is the third determination of the crisis semantics in our times. 


\section{THE DAWN OF HISTORICISM AND THE HISTORICAL MEANING OF CRISIS}

We are not very far, indeed, from the original, ancient meaning of the word, where "krisis" and "krinein" designated the turning point within a disease, but also a distinction, a separation and a decision, the roots of both actual "crisis" and "critique". What has been changed is the contemporary universalization of the word that makes it almost impossible to reduce it to a solid body of related meanings. The most important feature of the word that carries us in the XIX ${ }^{\text {th }}$ century that predetermines our current use is the systemic component of the phenomenon. A crisis is not a singular event, regardless of its outcomes; it is more likely the effect of this event over the constitution of the entity that has been affected by it. A tsunami is not yet a crisis, but its effects may determine one that is measured in the loss of life, in the lack of authority's responses, in the devastation and ruination that are left behind. Following Kuhn's expression in its mentioned work, a science is in crisis when the paradigm that constituted its fundamentals has been overthrown and has to be replaced by another (Kuhn, 1962).

In the XIX ${ }^{\text {th }}$ century, the paradigm that was set into question was the transcendent, the absolute as a point of reference for any cultural endeavor. The intensification of the historical conscience and the growth of historical schools in Germany brought forward the historical conditioned individual as an object of scientific inquiry. But historicism had to face one major aporia, since the individual was never considered something that could be the object of a scientific research and knowledge in general. On the ruins of German idealism, historicism was in need for a ground, an epistemological foundation of its premises and goals, but it had to succumb as a transitory movement that has carried us into modernity. But the dissolution of historicism is also the dissolution of the metaphysical commitments regarding time and its continuity, linearity and straightforwardness (Bambach, 1995). Part of the explosion of crisis related writings following the WW1 is nothing but a culmination of this public feeling of a loss of trans-historical foundation that has been expressed in Nietzsche's death of God, accelerated by the terrifying events of the war and the dismemberment of the old social-political and cultural institutions (Bambach, 1995). In fact, as Alan Megill suggests, in his book Prophets of Extremity, we may consider that the modern and postmodern language of crisis has a double folded origin, where we should include both the lost of transcendent dimension and the more influential dawn of the historicism which brought forward the loss of confidence in the teleological meaning of the historical process (Megill, 1985).

If the first phase of the crisis consciousness has as its catchy word the feeling of estrangement, of an abyss that took place of the old relation of human beings with divinity and its lawfulness, the second phase is more about the break of the historical continuity that still constituted the general frame of historicist worldviews (Megill, 1985). Even if Megill emphasizes the post-historicist crisis as the most important constituent of our current use of the word, the feeling of alienation that follows the dissolution of Cartesian-Kantian paradigm of the ego as the centre of thought, feeling and volition, goes along with the feeling of historical insecurity 
in shaping the actual landscape of our prejudgments and presuppositions. The inter-subjectival approach as the search for the constitution and the reality of "the other", the problem of relativism as the loss of confidence in the transcendent-authoritative criteria of truth and validity, are closely related with the contemporary debate about the loss of confidence in the rationality of the historical process. In his Meaning of History, Berdiaev relates any possibility of understanding the historical evolution and the historical events to the metaphysics of the eternity as the divine (celestial) time. We cannot conceive something like an intelligible history without taking into consideration its finality along with time's transcendental dimension (Berdiaev, 2006).

The connection is made thought the very idea of meaning. As we no longer have a dominant paradigm of epistemological truth, as deconstruction has become the final word of postmodernism, as the logic of our judgments is under constant assault, the concept of meaning became de-centered. That both truth and meaning are contextual determinate and perspectival, was already declared by Nietzsche more than one century ago. The historical approach of the $\mathrm{XI}^{\text {th }}$ century has been provoked by the dismissal of the German idealism, but it still retained much of the former's general conditions of scientific research. What had been looked for was the meaning of the individual and the singular events that may comply with the epistemological requirements of traditional science. Crisis sprung when both God and the historical meaning were declared missing.

We are probably not the most reliable witnesses of our present days, as we are not probably the best interpreters of our dispositions and feelings, and this is due to the fact that we are pre-judgmental by nature. The Cartesian account of unmediated states of mind became obsolete as the current, scientific "mind-philosophy" suggests. As any reader of Heidegger and/or of the post-Heideggerian hermeneutics knows, the condition for any interpretation is to set forward its own presuppositions which constitute the fore-structure of the interpretation itself. And this is a very difficult task. That is why, any statement, any investigation and any interpretation of something like a general contemporary view has to deal first with the interprete$r^{\prime}$ s own account of the object of inquiry. The meaning of this is that anything that sounds like a diagnosis of some contemporary line of thought is nothing more than a reflection of the author's own pre-disposing interests and individual narrative. But the very acceptance of these statements within a large audience may constitute a clue towards a generational disposition to relative and fragmentary discourses.

At the beginning of the $X X^{\text {th }}$ century, crisis was encountered as something external, which threatens, one by one, most of human social-cultural products and institutions, science, art, philosophy, social and political organizations. The spread and universalization of crisis language was indeed accelerated by the events of the WW1, but its roots were intellectual, as we may see if we take a look at the immense amount of writings that had dealt with this phenomenon. Within our introductory remarks, we said that our contemporary language of crisis is more internalized, more personal and more fragmented than that of the previous generations. Spengler's Decline of the West is seizing upon a general bankruptcy tendency of the western civilization while Fukuyama's last man from the end of history has to 
deal with its own discontents within a civilization that has succeeded in reconciling man's most intimate desires. The internal, individual referentiality of postmodern discourses about crisis that may be seen especially in everyday language may be a consequence and a symptom of an ego-oriented generation, but this by no means an explanation. There is more to this, as I think that the change of discourse is a sign of a more subtle, unconscious perception underlying it, and this is our specific historical approach of contemporary events and even states of mind.

\section{APORIA OF RELATIVISM: KOLAKOWSKI}

We already said that crisis is one of the most salient features of our contemporary world, the evidence of this being the amount of crisis discourses, regardless if we consider here our personal affairs, the political, religious, educational, ecological and cultural domains of our lives. We need only to open the first pages of our newspapers, turn on our TV's or search the web. Every single current event that represents an interruption of our daily routine is considered a crisis. At the very moment this page was written, the burning problem was that of the refugees from Syria and the Arab World that stand at the gates of Europe, and the debate was whether this was a real refugees crisis or an invasion of Europe.

It may seem that even when we do not encounter crisis as a closing critical external threat, we are in a constant search for different types of crises therefore we are so eager to apply the term even if the situation does not require it. Following the deconstructivist trend of the last century, we may find here that there is nothing more than some language game or some discourse related issues. In fact, our issue may turn out to be just a designation problem that may be deconstructed such as the phenomenon that lies behind it turns out to be just a disparate series of events that lack the connection that may entitle them all to be subsumed within one large phenomenon. But the very phenomenality of the crisis situations, the way the events are perceived and designated as crises, is our main concern here, in order to relate it to a subtle, unconscious, modified perception of time and historicity.

Well known for his critical analyses of the Marxist thought in his three volume history of the rise and fall of the socialist and communist ideology, the Polish thinker Leszek Kolakowski uses his insights in order to address some of the main issues that he considers to describe the contemporary world, especially the political, religious and scientific. Considering the fragmentary and essayistic approach of Kolakowski that falls out of his more systematic political works, we will not find here a general description or a diagnosis of his generation, but if we take a look of his essays that are spread over some decades at the confluence of the XX and XXI centuries, we may be able to trace some features that may be used to retain and understand one of the most reliable testimonies of the generation that precedes us.

The reader of his collected essays from the anthology Is God Happy? is made conscious of some of the most general trends of the civilization of which he is an inhabitant, the most important of these being the relativism, the loss of historicity and the anguish or anxiety that was brought upon us by the death of God (Kola- 
kowski, 2012). There is a point here that deserves to be highlighted and this is the fact that Kolakowski does not impose upon us a diagnosis of the current world, the latter is not morally appraised, and that means that we are not told if the world we are living in is better or worse than its preceding ones. Witnessing the calamities of both social nationalism and communism, Kolakowski is still able to leave us with both the impression that it may still be the best world of all possible ones and the feeling of nostalgia for a world whose bindings to the absolute was not lost.

We usually oppose what is absolute to what is relative, and relativism, even if it was not designated as such, is the conception that initially originated somewhere in the modern era by Hume and its followers, who had reduced the truth to the connection between external and internal impressions. Hegel's trust in the historical development of the Absolute Spirit have inoculated the idea that only in history we may find the criteria of appraisal for any scientific, moral, philosophical or aesthetical happenings. That history will judge (us) all is nothing else than the popular restating of one of the most influential conceptions that has defined our intellectual landscape along the centuries. Nietzsche was the one that has made us conscious of the contradiction we were not ready to front, that between our constant desire for certitude, truth, eternity, and the other reality, that of the world we are afraid of, of constant pain and misery that was best described by Schopenhauer. As Kolakowski tells us in The Death of the Historical Man, the essay of which most of our discussion is focused, contemporary relativism is one of the consequences of the successive deaths of the meaningful nature, of God and of historicism (Kolakowski, 2012).

Replacing both religion and nature's domination over the phenomenal world at the beginning of the XIX ${ }^{\text {th }}$ century, historicism was the last word of the Absolute, but it soon got caught in some major contradictions, since the belief in some immutable force of history could not be reconciled with the principle of historicism itself, that the truth is historically conditioned. But since the concept of truth had been made dependent of each historical époque, of its inhabitants and of their particular worldview, there is only one step to take in order to arrive at its anticipated destination, the idea that there is no truth at all. Historicism has turned against itself, leaving the place open for today's nihilism and relativism (Kolakowski, 2012). But even if historicism was the final major turning point regarding the relativization of truth, it had retained the post-Hegelian teleological belief in some rational succession of historical events that will finally succeed to overcome the misery of particular historical happenings. But, as the relativist position became increasingly stronger, what had been lost is the very trust in the meaning of history that has been brought forward by the $X X^{\text {th }}$ century scientific dissolution of our illusion that there is one final stage of our historical evolution, one perfect society that will conclude and fulfill human nature and its desires.

Even if Kolakowski does not use the word crisis to describe his view about the contemporary world, it seems that we have arrived at a crossroads where we should decide which path we should follow and, as we already saw, this is the original meaning of the word itself which represents both the turning point and the decision for one direction or another. The spread of the crisis related discourses, the seemingly constant danger of crisis that may affect both our private and public 
affairs, may be not just a turn of speech, but the outcome and the expression for the general feeling of discontent that is an outcome of some contradictory dispositions that affect our most important desires, anticipations and resolutions.

In fact, the one domain that had successfully embraced the relativist position is the scientific one, its contention with relativism being expressed as the pragmatic vision that the only things that count regarding the problem of truth are the scientific condition of acceptance for its proposition and theories. There is no need for a universal concept of truth, there are no general truth conditions, since it became obvious that scientific truth is dependent on our instrumental means of observation. Scientism, in Kolakowski's words, the worship of scientific progress, became the fundamental framework of all our contents and intellectual possibilities (Kolakowski, 2012), but there is a problem for us turning to science for answers, since the scientific work and discourse is only intelligible for a minor category of people having some scientific background. What happened is that even when we succeed to appropriate the scientific pessimism regarding the authoritative universality of truth, morality, religion or other domains that shape our everyday lives, most of us find it impossible to overcome their metaphysical longings for the rest and comfort of what is universal, eternal, therefore supra-historical, and we already mentioned the words of Berdiaev regarding the salvation of history's misery through relating it to what he calls the celestial history.

\section{HEIDEGGER'S QUARREL WITH HISTORICISM}

\section{In Allan Megill's book from 1985, Prophets of Extremity, we may read that}

In one or another of its versions, crisis is the most widely held assumptions of twentieth century thought. Its very pervasiveness leads to its mindless repetition. More often than not, it is evoked rather than explained and defended. Unchallenged, it is exempted from any sort of critical examination (Megill, 1985, p.111).

We have already evoked this type of crisis assumption when we turned to the contemporary spread of various crisis related discourses, but we have done it by relating it to both public and private folk discourses, and not so much to the intellectual landscape of our times. The difference is that we are no longer confronted with major cultural works that deal explicitly with some kind of crisis, but, at the same time, the crisis language has somehow invaded our everyday lives. As we think, this constitutes the radicalization of the crisis consciousness that goes along with the lack of its critical examination. While, in the first half of the century, the content of the word was still largely developed and analyzed, the contemporary use of the term is deploying it in relation to anything whatsoever.

It is not our concern here to offer an analysis of the relationship between the intellectual landscape of one generation and the everyday dimension of its private and public life, and it could be held that the transition goes both ways. It may be the case that an opinion, a conception, or a word is first proposed in the public space through common language and then it may be further conceptualized, ana- 
lyzed, depicted in paintings, music or poetry, but the reverse may still be valid. If we follow Megill's analyses, we are living in a world that is highly dominated by different responses to the crisis that affected the cultural, scientific and political world of the beginning of the XXth century (Megill, 1985). Accelerated and completed by the two World Wars, the crisis embraced almost all of the intellectual life of Europe and both modernism and postmodernism are seen like a response to that crisis. This is made obvious by portraying some of the works that have been created done by some major figures in the lyric and figurative art of the $X X^{\text {th }}$ century, the theory of science, philosophy and so on.

Choosing one figure that best represents the landscaping of our everyday and intellectual life is always subject to criticism for being an arbitrary decision. This being said, we will shortly turn our gaze to one philosopher in whose eyes, even the difference between the everyday and intellectual life areas is highly problematic, the one that, at the beginning of the $X X^{\text {th }}$ century had tried to gain our attention over some the lack of grounding for some common held distinction that constitutes the background of our lives and worldviews. This is an understatement of Martin Heidegger's work, since the later, including his recently published lectures before Sein und Zeit, constitutes one of the largest corpus of writings in our times. His influence had ups and downs, unfortunately his political implication makes it very hard for someone to approach him without prejudice, nevertheless, he is one of the thinkers that have definitively marked the contemporary philosophy, as most of post structuralism is indebted to him, but he also made his presence felt in the theory of science and even psychology.

Heidegger's first lectures from Freiburg were delivered just after the end of the First World War, in 1919, therefore he is one of our best witnesses of the acceleration of the crisis consciousness at the beginning of the century. Heidegger's major interest in the crisis that spread all over Germany following the horrors of the war was, at least at the beginning, the organization of the German University and philosophy's situation and its role within the totality of sciences and disciplines that were being professed. But, as we may see from his first lecture, philosophy is not seen as one particular discipline between the others, since its main object is everyday life considered as factual and historical ${ }^{10}$. Besides that, Heidegger does not regard crisis as the outcome of some special situation, like the world war, but as the destiny and finality of the European civilization that was created on the pillars of western metaphysics (Heidegger, 1962). The relationship between the historicity and fact of human life, the definition and role of philosophy and the history of western metaphysics is made through the idea of the forgetfulness of being which constitutes the red wire that sets the destiny of European history. Heidegger's crisis is not a concept that may be regarded as a determination of a specific problem that affects one or some more particular life domains, but, at the same time, he criticizes the implosion of the crisis related writings like Spengler's one dealing with some dissolution of the western spirit. For Heidegger, the idea of a crisis, rarely expressed as such, is some-

10 The references for this statement may be found within the majority of Heidegger's lectures during his first stay in Freiburg between 1919 and 1923, starting with The Idea of Philosophy and the Problem of Worldview from 1919, and ending with Ontology. The Hermeneutics of Facticity from 1923. 
thing that is an outcome of a more refined transition, the one that we have spoke about, that between the intellectual and everyday areas of human life. If we have mentioned before the forgetfulness of being, it is obvious that there is only a minor category of people that may relate their various crises to something so abstract that is a subject only to the understanding of the same minority.

At the same time, we should highlight the difference brought forward by Heidegger between the history as the sequential succession of events, often determined by him as historicism, and the crucial historical dimension of human life as such. The dawn of historicism and its trust in some benevolent, linear, historical progress and its finality still left unshaken the paradigm of time as a unidirectional succession of events. What was lost at the beginning of the $X X^{\text {th }}$ century was the belief that this succession will carry us into some final age of the mankind that was supposed to be the best social order that could ever exist. Nevertheless, the objectification of time and historical events that constituted the fundamental condition for the rise of the historical schools was perceived and appropriated by some as the intellectual framework that enabled them to declare crisis as an end of times, while the apocalyptical post-war imagery was mainly their triggering factor. But the objectification, the reification, of historical events means an objectification of life events. Life itself got imprisoned in some rigid epistemological representations that were supposed to make it available for objective historical research. But, as Heidegger calls our attention upon it, in this way life becomes un-livable, it is exhausted and deprived of the very sense of living, which is not a series of objectified experiences but a more intricate complexity of meaningful relations with the world we disclose each time we encounter it. Life should always be perceived considering its factual situation, while its fundamental historicity should only be retained as a complexity of interconnected meaningful relationships, not a movement towards some supposed end but a constant encounter and appropriation of both its ends and its means (Heidegger, 2001).

Life's factual situations should be examined in order as being disclosure of the encountered beings and of life itself to become available for critical examination, and this constitutes the role and main purpose of philosophical research. The forgetfulness of being as the history of Western civilization has the very meaning of this flight of life from its genuine possibilities This flight will be called by Heidegger the inauthenticity of everyday human being or Dasein, as it is best expressed in the impersonal dimension of public space (Heidegger, 1962). Resting on tradition as a series of calcified events, without it being interrogated starting from the current factual situation of life, is able only to empower this inauthenticity, leaving life at the disposition of some public held conceptions whose only grounds are the fact that they are believed by the vast majority of us.

\section{THE USE AND ABUSE OF HISTORY: NIETZSCHE}

The idea of crisis as the end of European civilization following the dismissal of the Western metaphysics culminates in Heidegger's lectures about Nietzsche, while the latter is seen as the last metaphysician of European philosophical thinking. While Nietzsche is usually seen as the one who's claimed death of God ends one 
époque and carries us in to the nihilistic, relative or perspectival post-modernity, considering our line of thoughts, we will consider here one of his early writings, his second Untimely Meditation from 1874, about The Use and Abuse of History for Life.

We should be aware of not reading Nietzsche's nihilism as a direction to follow, as a declaration of intention, but more as a diagnosis of his present times and as a statement that involves him and his contemporaries: we have killed God, we have freed ourselves from the constraints of an imposed morality, we are now able to decide our own faiths. What is to be done now, when we are facing the abyss that lies before us? This is something like an emergency call, and by calling our attention upon it, Nietzsche may be seen as the genuine crisis thinker, the one whose writings are the point of departure for a whole generational crisis meditation. It is their reaction while facing the abyss that people depart and makes them part ways. The vast majority of people will turn away, looking for reassuring grounds, while for few people the abyss will only empower their creative, aesthetical impulses. The use of aesthetical metaphors in Nietzsche's writings may only be understood as imposing themselves over a space that was left open. While there is no God, we should not rely on nature either, since it is only an agglomeration of irrational brute forces. Any work of art supposes that there is an empty space to be filled.

Turning away from something that may threaten us usually means turning ourselves back to some previous situation, which was less frightening. When we may find no place to stand, we return to history in order to search for some solid grounds that may help us to recover from the dizziness which affects us while we are one step away from the abyss. But there seems to be a paradoxical image here, while the most assuring things in history are the un-historical or trans-historical events and beings, the ones that stand at the beginning of the history. History may be seen as a chain of fortunate or unfortunate events, while the meaning of these could only be perceived through a supra-historical confrontation with their transcendent nature, as originating from God or other deities. As we have already seen, in face of the loss of God or some other benevolent spirit, historicism had considered as its only possible replacing option the trust in the rational order of historical events, the linear succession of time that will finally end in one perfect society that will reimburse all the historical misery that mankind had to go through during its preceding periods.

But, beside the analytics of his present times, Nietzsche will address his contemporaries a merciless critique, as their capacity for a genuine historical perspective that will help life to empower its creational behavior is shadowed by their tendency for the objectification of historical events and personalities. In order for history to constitute a real asset for human life it has to be addressed from a definite perspective, a life context that may allow a genuine decision to be made regarding both past and the future. This is opposed to the livresque, critical observation of past events that is a hallmark of the historical research in that century, that may only serve to disguise the real intentions of an objective critique. What is searched for within this tendency to objectiveness and impartiality is only a sanctioning of our indifference (Nietzsche, 1983).

As the most genuine observer of crisis, Nietzsche is the one that for the first time thinks the double-folded meaning of crisis, as the latter is not just a consequence 
of the loss of transcendental authorities but, at the same time, a crossroads and an opportunity for a decision. Writing in the second half of the historicist siècle, witnessing its rise and its intellectual consequences, Nietzsche is our most reliable witness regarding the double play between the historical meanings and the crisis mentality. But, beside that, Nietzsche is also one of the most contemporary writers within the intellectual tradition of Western civilization, the trend setter for the development of post-modern thinking, as he is present and presentified in the works of some of the most representative writers of this line of thought, like Derrida, Foucault, Deleuze and the list may very well continue. It may be the case that, considering Nietzsche the last metaphysician, we are not yet ready to part way with metaphysics. If Nietzsche is declaring God dead, maybe we are trying to re-create the very moment of its death, just for a reconsideration of what we have done. Maybe it is the circularity of time expressed as the Eternal Return that catches our eyes, but its interpretation may vary according to one's possibilities of internal examination.

As history is becoming increasingly personalized and fragmented, as we now have individual narratives, or, as Kolakowsky says, we are not just living history, we create it (Kolakowski, 2012), our generational disposition towards all types of crises may turn out to be a cry over an internal conflict that affects our lives and welfare. While we should not look for some universal solution, while the eschatological discourses about the destiny of the mankind seem so meaningless, we might only point to one possible direction, and this was the reconsideration of modifying perception of time and history that may constitute one of the grounds for our eagerness to adopt and to embrace the crisis figure, even if and when we do it like a figure of speech.

\section{NOTES}

This work was cofinaced from the European Social Fund through Sectoral Operational Programme Human Resources Development 2007-2013, project number POSDRU/159/1.5/S/140863, Competitive Researchers in Europe in the Field of Humanities and Socio-Economic Sciences. A Multi-regional Research Network.

\section{REFERENCE}

Bambach, C. R. (1995). Heidegger, Dilthey and the Crisis of Historicism. Ithaca, New York: Cornell University Press. Berdiaev, N. (2006). The Meaning of History. New Brunswick: Transaction Publishers, translated by M. N. Banerjee.

Megill, A. (1985). Prophets of Extremity: Nietzsche, Heidegger, Foucault, Derrida. Berkeley, New York: University of California Press.

Fukuyama, F. (1992). The End of History and the Last Man. New York: The Free Press.

Heidegger, M. (1962). Being and Time. Oxford: Basil Blackwell, translated by J. Macquarrie and E. Robinson.

Heidegger, M. (2001). Phenomenological Interpretations of Aristotle, Initiation into Phenomenological Research. Bloomington, Indiana: Indiana University Press, translated by R. Rojcewicz.

Kolakowski, L. (2012). Is God Happy? Selected Essays. New York: Penguin Books.

Kuhn, T. (1962). Structure of Scientific Revolutions. Chicago: University of Chicago Press.

Nietzsche, F. (1983). Untimely Meditations. Cambridge: Cambridge University Press, translated by R. J. Hollingdale. 